\title{
How Do the Volume and Maturity of Debt Relate to Investment Efficiency? The Case of Asia
}

\author{
Ehsan Poursoleiman (Urmia University, Iran) \\ Dr. Gholamreza Mansourfar (Urmia University, Iran) \\ Assoc. Prof. Dr. Sazali Abidin (Lincoln University, New Zealand)
}

\begin{abstract}
This study aims to investigate the impact of debt volume and maturity on investment efficiency. It also analyzes the role of debt maturity in the association between debt volume and investment efficiency. The sample consists of 8,741 firm-year observations from 1,301 Asian corporations, covering the period 2007-2017. Financial leverage is employed as a proxy for debt volume as well as short-term debt for debt maturity. The findings reveal that debt volume and short-term debt are inversely related to investment efficiency. It also shows that the negative relationship between financial leverage and investment efficiency is weaker (closer to zero) for firms with higher use of short-term debt than those with lower use of short-term debt. This paper tries out agency and information asymmetry theories and provides practical implications regarding the optimal capital structure for firms headquartered in Asia.
\end{abstract}

\section{Introduction}

In perfect markets where the tax on revenue and agency problems do not exist, all corporates investments result in improving firms' value. Whereas, in imperfect markets, information asymmetry and agency problems make firms invest inefficiently which in turn may lead to the decease of firms' financial performance. Acceptance of lucrative projects and rejection of poor projects lead to efficient investments. Conversely, embracing loss-making activities and rejecting favorable opportunities cause over-investment and under-investment problems, respectively. Managers' private incentives, such as the effort aversion and the desire for a quiet life intensify underinvestment problems (Bertrand \& Mullainathan, 2003), and managers' motivations for building an empire and their inconsiderations increase the risk of over-investment problems (Blanchard, Lopez-de-Silanes, \& Shleifer, 1994; Aggarwal \& Samwick, 2006). Beside, managerial entrenchment (Shleifer \& Vishny, 1989) and over-selfconfidence (Heaton, 2002) adversely influence investment efficiency. All these inclinations originate from agency conflicts and high costs of monitoring (Jensen, 1986; Richardson, 2006); therefore, the gap between managers and stakeholders push the firms toward investment inefficiency (Jensen \& Meckling, 1976). Thus, the only possible way to keep firms away from the inefficient investment is to eliminate this gap and conflict. Financial leverage (debt volume) could tighten the gap between managers and outsiders, and as a result, can mitigate agency costs (Poursoleiman, Mansourfar, \& Abidin, 2020). It imposes strict controls over managers' decisions and their incentives for building empire by increasing the number of contract renewals and imposing strict requirements such as keeping a definite return on asset ratio (Lang, Ofek, \& Stulz, 1996; Khan, Kaleem, Nazir, \& Khan, 2012). Thus, debt could enhance investment efficiency through mitigating over-investment problems.

Financing constraints make firms unable to channel all the available funds into projects, which may drive firms into under-investment problems (Myers \& Majluf, 1984). Increasing in risk puts significant barriers on firms access to financial resources and consequently raises financing costs. In grave conditions, the risk could impede firms from financing and as a consequence, lead them to financial distress point (Biddle, Hilary, \& Verdi, 2009). Incidentally, it is the debt that increases the risk (Tsai \& Gu, 2007; Hsu \& Jang, 2008; Koh, Lee, \& Boo, 2009). In other words, an increase in debt level is associated with an increase in firms' risk, so financial leverage (debt level) could have a considerable detrimental effect on investment efficiency through the risk channel.

Theoretically, financial leverage has both positive and negative impacts on investment efficiency. It could enhance investment efficiency by imposing strict controls over managers and on the other hand it could exacerbate investment efficiency by increasing the risk and costs of financing. Therefore, a question is being raised here which this paper intends to address: What is the experimental effect of financial leverage on investment efficiency?

Moreover, financial leverage is made up of short-term and long-term debt. Short-term debt brings liquidity risk which can block a significant amount of financial resources; therefore, short-term debt can increase investment inefficiency through blocking available funds. In addition, short-term debt as a sub-scenario of financing could mitigate agency conflicts between the two sides more efficiently than long-term debt because of its shorter durations of contracts (González, 2017; Poursoleiman et al., 2020). Therefore, short-term debt can also increase investment efficiency by tightening the gap between the two sides (Childs, Mauer, \& Ott, 2005; Gomariz \& Ballesta, 2014). As a result, financial leverage and short-term debt affect investment efficiency through the similar channels. They both restrict the accessibility to financial resources and also mitigate information asymmetry or agency conflict. Therefore, these two factors are expected to have an analogous correlation with investment efficiency dimensions - they decrease investment efficiency through decreasing financial resources and increase 
investment efficiency through mitigating agency conflicts. As a result, if financial leverage has an inverse association with investment efficiency, short-term debt also should establish such relationship with investment efficiency. Therefore, we aim to investigate this claim in the present study.

The remainder of the paper is organized as follows: In section 2, the existing literature on the role of debt level and maturity on investment efficiency is reviewed and the research hypotheses are developed. In section 3, the research design, models, evaluation of variables and the sample are introduced. In section 4, the results are presented and finally, in section 5 the main conclusions of this paper are presented.

\section{Literature Review and Hypothesis Development}

Investment efficiency is accomplished through appropriate injection of financial resources into operating activities. Investment and non-investment per se do not necessarily lead to investment efficiency, only investing in profitable projects in terms of net present value, as well as not investing in poor projects, lead to investment efficiency. According to finance theories, three factors exert considerable influences on investment efficiency: (1) financing constraints and costs, (2) agency problems, which refer to the conflict of interest between managers and stockholders, and (3) information asymmetry. The disagreement between managers and stockholders generates agency problems and information asymmetry. Also, the risk of high debt brings financing constraints and difficulties.

Flynn (2017) concluded that an increase in financial leverage is associated with a decrease in future external financing. Incidentally, in imperfect markets, financing precedes investment and firms finance in order to supply funds for investing in projects; therefore, financial leverage decreases future investment through the financing and risk channel (Bao, 2010; Flynn, 2017; Barbiero, Brutscher, Kolev, Popov, \& Wolski, 2018; Danso, Lartey, Fosu, Owusu-Agyei, \& Uddin, 2019). Bao (2010) predicted that decreasing in investments makes firms unable to employ and pursue growth and profitable opportunities, so a negative relationship between financial leverage and investment leads to investment inefficiency. Therefore, financial leverage decreases investment efficiency by increasing financing costs. Moreover, when debt level in capital structure is high, managers struggle to keep a great deal of money on hand and avoid investing these amounts in projects lest they might be unable to repay the debts at maturity (Jensen, 1986). Therefore, financial leverage could make managers lose their incentives to invest in positive projects in terms of net present value. So, financial leverage decreases investment efficiency by blocking financial resources and increasing financing costs.

In accordance with Myers (1977), in external debt financing, if the investment profit is not sufficient to be fairly distributed among creditors, debtors will receive more than stockholders because of the priority they possess. As a result, the incentive of managers-stockholders coalition to invest in positive projects will decrease. Surprisingly, leveraged firms will have fewer growth opportunities because of rejecting positive projects (Noravesh \& Yazdani, 2010). Therefore, increasing in financial leverage is probably associated with decreasing in investment efficiency. It can be concluded that financial leverage is inversely related to investment efficiency.

In debt financing, managers block a great deal of funds due to the fearing of inability to reimburse the debt's principal and interests at maturity. Incidentally, short-term debt, as an option of borrowing, imposes higher liquidity risks to firms, which makes managers more conscious and aware of maturity dates (Zhaoguo, Weifeng, \& Jing, 2008). Therefore, short-term debt seems to cause under-investment problems, and as a result, it is expected to increase investment inefficiency.

To sum up, the mentioned experimental and theoretical studies suggest that financial leverage and short-term debt have a meaningful effect on investment efficiency. Financial leverage exacerbates investment efficiency by increasing financing constraints and decreasing the accessibility of financial resources, and also short-term debt blocks managers' free cash flow, which can intensify under-investment problems and as a result decreases investment efficiency. Therefore, short-term debt is expected to cause financial leverage to have an inverse effect on investment efficiency through decreasing or blocking financial resources. Thus, the negative effect of financial leverage on investment efficiency through decreasing cash flow is mainly due to the presence of short-term debt. Moreover, these two factors are expected to have an inverse relationship with investment efficiency and it also expected that the coefficient between financial leverage and investment efficiency is higher than the coefficient between short-term debt and investment efficiency. Thus, the first hypothesis of this study is as follows:

H1: Financial leverage and short-term debt exacerbate investment efficiency.

Information asymmetry theory can also demonstrate how financial leverage and short-term debt are related to investment efficiency. Information asymmetry significantly affects agency conflicts and costs, which both have meaningful effects on investment efficiency. Previous empirical studies, such as Verdi (2006), Biddle and Hilary (2006), Biddle et al. (2009), Chen et al. (2011), Morellec and Schürhoff (2011), Zhai \& Wang (2016) and Li, He, and Xiao (2019), predicted that an increase in information asymmetry is associated with a decrease in investment efficiency. Incidentally, financial leverage and short-term debt play a decisive role in decreasing information asymmetry (Flannery, 1986; Ortiz-Molina \& Penas, 2008; Barbiero et al., 2018). Therefore, financial leverage 
could affect investment efficiency through the channel of information asymmetry. In this paper, this channel will be studied from the viewpoints of timing, pecking order and signaling theories.

From the perspective of timing theory of Modigliani and Miller (1958), firms finance through borrowing in order to repurchase stocks when the stock price is below the actual value and issue new stocks when the stock price is above the actual value. According to market participants, in this process, debt financing and equity financing have occurred because of false pricing. Stockholders, therefore, infer that in the case of debt financing, the actual value exceeds the market value, and conversely in the case of equity financing, the market value surpasses the actual value. Therefore, financing activities reports positive and negative news to the market, which can mitigate information asymmetry and disclose firms' internal news about managers' incentives. Following timing theory, signaling theory of Ross (1977) claims that financial leverage mitigates information asymmetry because it is a criterion of management performance and could mitigate management's misbehavior. Pecking order theory of Myers (1984) presumes that information asymmetry and its consequences - adverse selection and moral hazard - create hierarchies. According to this theory, managers prefer to finance through resources that get the least affects from asymmetric information. Therefore, accumulated profit and reserves as internal financing resources bring the least costs to firms, and equity financing as an external financing scenario generate the most costs $(\mathrm{He}$, Lepone, \& Leung, 2013). Furthermore, the maintenance of current stockholders and avoidance of equity financing sent positive signals to the capital market, and debt financing indicate that the firm has an appropriate future financial position. Thus, debt financing (financial leverage) could significantly decrease information asymmetry through signaling (Andres, Cumming, Karabiber, \& Schweizer, 2014).

According to agency and information asymmetry theories, financial leverage and short-term debt mitigates information asymmetry. Moreover, short-term debt can alleviate agency conflicts more efficiently than long-term debt because of its shorter maturity (González, 2017). Childs et al. (2005) and Gomariz \& Ballesta (2014) claimed that short-term debt can mitigate over-investment problems. As a result, the negative relation between financial leverage and investment efficiency is expected to be weaker (closer to zero) for firms with higher use of shortterm debt than those with lower rate of short-term debt. The following hypothesis is developed to test this expectation:

H2: The impact of financial leverage on investment efficiency is less negative for firms with higher use of shortterm debt.

\section{Research Design}

\subsection{Model Specification}

Model 1 and 2 have been used to analyze $\mathrm{H} 1$ and $\mathrm{H} 2$, respectively. These models were employed by Gomariz and Ballesta (2014) and Benlemlih and Bitar (2018) and have been developed from Biddle et al. (2009) and Chen et al. (2011) studies.

$$
\begin{gathered}
\text { Efficiency }_{i t}=\beta_{0}+\beta_{1} \text { Lev }_{i t}+\beta_{2} \text { STDebt }_{i t}+\beta_{3} i t+\beta_{4} \text { Cash }_{i t}+\beta_{5} M T B_{i t} \\
+\beta_{6} \text { LnAge }_{i t}+\beta_{7} \text { Tang }_{i t}+\beta_{8} \text { ROA }_{i t}+\beta_{9} H P_{i t}+\varepsilon_{i t}
\end{gathered}
$$

where Efficiency represents investment efficiency, Lev represents financial leverage, STDebt is short-term debt ratio, Size is the size of firm, Cash represents cash, MTB is the market to book value of assets, LnAge is the age of firm, Tang represents tangible assets, $R O A$ is the return to assets ratio, and $H P$ is a dummy for financing constraints.

Also, in order to minimize the concern that financial leverage and short-term debt may link to each other; two separate regressions were estimated based on Model 1: (1) regression of investment efficiency on financial leverage and control variables (2) regression of investment efficiency on short-term debt and control variables.

(2)

$$
\begin{aligned}
& \text { Efficiency }_{i t}=\beta_{0}+\beta_{1} \text { Lev }_{i t}+\beta_{2} \text { STDebt }_{i t}+\beta_{3} \text { Lev } \times \text { DumSTDebt }_{i t}+\beta_{4} i t \\
& +\beta_{5} \text { Cash }_{i t}+\beta_{6} \text { MTB } B_{i t}+\beta_{7} \text { LnAge }_{i t}+\beta_{8} \text { Tang }_{i t}+\beta_{9} R O A_{i t}+\beta_{10} H P_{i t}+\varepsilon_{i t}
\end{aligned}
$$

As shown in the literature review, short-term debt could reduce information asymmetry more efficiently than long-term debt; incidentally, it was shown that information asymmetry could have a considerable impact on investment efficiency. Therefore, it is expected that in $\mathrm{H} 2$, the inverse relation between financial leverage and investment efficiency is less negative (closer to zero) for firms with higher use of short-term debt. As a result, similar to Gomariz and Ballesta (2014), in this study, an interaction effect has been considered between financial leverage and a dummy variable for the proxy of short-term debt (DumSTDebt), which takes 1 if the ratio of shortterm debt to total debt is above the median and otherwise, it takes 0 . Thus, Lev $\times$ DumSTDebt represents an interaction effect. In Model 2, $\beta \_1$ indicates the impact of financial leverage on investment efficiency for firms with lower use of short-term debt; $\beta \_1+\beta \_3$ represents the effect of financial leverage on investment efficiency for firms with higher level of short-term debt than the median. 


\subsection{Variable Measures}

\section{Dependent variable: investment efficiency}

Previous studies suggested employing the growth opportunities model for measuring investment efficiency. The concept of this model is that growth opportunities should explain firms' capital investments; therefore, any failure in explanation and deviation indicates the occurrence of inefficient investment. Therefore, Model 3, designed by Biddle et al. (2009), was utilized to measure investment efficiency.

(3)

$$
\text { Investment }_{i t}=\beta_{0}+\beta_{1} \text { SaleGrowt }_{i t-1}+\varepsilon_{i t}
$$

where Investment is the change in tangible and intangible assets from the last year $(t-1)$ to the current year $(t)$ divided by total assets and SaleGrowth is the rate of change in sales from $t-2$ to $t-1$.

Positive errors in Model 3 indicate that investment exceeds growth opportunities, so the value of such error is the value of over-investment. On the other hand, negative errors in this model indicate that investment could not follow growth opportunities; in other words, managers did not invest enough in projects, so the digit of negative error is the value of under-investment. Absolute values of both positive and negative errors measure investment inefficiency. Therefore, to determine investment efficiency, the absolute values were multiplied by -1 .

\section{Independent variable: financial leverage}

The ratio of total debt to total assets is used in order to measure debt level or financial leverage.

\section{Independent and moderator variable: short-term debt}

The ratio of short-term debt to total debt is used to measure the level of short-term debt.

\section{Control variables}

Based on previous literature and theories, some control variables were used as follows: Size = natural logarithm of total assets; Cash $=\neg$ cash divided by total assets; LnAge $=$ natural logarithm of firm age; MTB $=$ market to book value of assets; Tang $=$ ratio of tangible assets to total assets; ROA = return on assets; $\mathrm{HP}=$ takes 1 if HP index is above the median and 0 otherwise. HP index was measured by Hadlock and Pierce (2010) and defined as: $-7.373 \times$ (natural logarithm of total assets $)+0.043 \times$ (natural logarithm of total assets) $2-0.04$ (the age of firm)

\subsection{Sample}

The sample includes firms from the Asia continent during 2007-2017. There are in sum 8,741 observations. Data were obtained from the Thomson Reuters database. Moreover, in order to mitigate the influence of outliers, all variables were winsorised at $2 \%$ and $98 \%$ levels. Table 1 shows the sample distribution by country.

\begin{tabular}{|l|c|c|}
\hline Country & No. Firms & Percentage \\
\hline China & 170 & $13.07 \%$ \\
\hline Hong Kong & 124 & $9.53 \%$ \\
\hline India & 105 & $8.07 \%$ \\
\hline Indonesia & 39 & $3.00 \%$ \\
\hline Japan & 425 & $32.67 \%$ \\
\hline Malaysia & 53 & $4.07 \%$ \\
\hline Philippines & 26 & $2.00 \%$ \\
\hline Singapore & 43 & $3.31 \%$ \\
\hline South Korea & 118 & $9.07 \%$ \\
\hline Taiwan & 133 & $10.22 \%$ \\
\hline Thailand & 39 & $3.00 \%$ \\
\hline Turkey & 26 & $2.00 \%$ \\
\hline Total & 1301 & $100 \%$ \\
\hline
\end{tabular}

Table 1. Sample Distribution by Country

\section{Results}

\subsection{Descriptive Statistics}

Table 2 provides descriptive statistics for the variables. The mean of financial leverage (Lev) is 0.361 which indicates that the firms use less debt compared to equity; in other words, the ratio of debt to total assets is less than the ratio of equity to total assets. The mean of short-term debt ratio (STDebt) is 0.497 , indicating that on average, the firms use equal amounts of short-term debt and long-term debt. 


\begin{tabular}{|l|c|c|c|c|c|c|}
\hline Variable & Mean & Median & Maximum & Minimum & Std. Dev. & Obs. \\
\hline Investment & 0.030 & 0.014 & 0.259 & -0.096 & 0.065 & 8741 \\
\hline Efficiency & -0.036 & -0.023 & 0.000 & -0.280 & 0.040 & 8741 \\
\hline Lev & 0.361 & 0.349 & 0.728 & 0.079 & 0.153 & 8741 \\
\hline STDebt & 0.497 & 0.517 & 0.978 & 0.000 & 0.301 & 8741 \\
\hline Size & 19.147 & 19.191 & 24.931 & 14.145 & 2.327 & 8741 \\
\hline Cash & 0.106 & 0.076 & 0.467 & 0.002 & 0.101 & 8741 \\
\hline MTB & 2.313 & 1.630 & 10.551 & 0.430 & 2.064 & 8741 \\
\hline LnAge & 2.796 & 2.970 & 3.762 & 0.112 & 0.805 & 8741 \\
\hline Tang & 0.328 & 0.300 & 0.822 & 0.004 & 0.203 & 8741 \\
\hline Roa & 0.076 & 0.062 & 0.287 & -0.056 & 0.068 & 8741 \\
\hline HP & 0.587 & 1.000 & 1.000 & 0.000 & 0.492 & 8741 \\
\hline SaleGrowth & 0.127 & 0.083 & 1.055 & -0.311 & 0.236 & 8741 \\
\hline
\end{tabular}

Investment is the change in tangible and intangible assets from $t-1$ to $t$ scaled by total assets; Efficiency is the absolute value of residuals of investment model of Biddle et al. (2009) multiplied by -1 ; Lev is the ratio of total debt to total assets; STDebt is the ratio of short-term debt over total debt; Size is the natural logarithm of total assets; Cash is the ratio of cash to total assets; MTB is the market to book value of assets; LnAge is the natural logarithm of firm age; Tang is the proportion of tangible assets over total assets; $R O A$ is the return on assets ratio; $H P$ takes 1 if HP index is above the median and 0 otherwise. HP index was measured by Hadlock and Pierce (2010) and is calculated as: $-0.737 \times$ (the natural logarithm of total assets $)+0.043 \times(\text { the natural logarithm of total assets })^{2}-0.04 \times($ firm age); and SaleGrowth is the rate of change in sales from $t-2$ to $t-1$.

\section{Table 2. Descriptive Statistics}

Table 3 presents the Pearson and Spearman correlation matrices for the variables. Correlations between variables are not high, therefore, collinearity is not likely to be a problem in this study.

\begin{tabular}{|c|c|c|c|c|c|c|c|c|c|}
\hline Pearson Spearm & Lev & STDebt & Size & Cash & MTB & LnAge & Tang & Roa & HP \\
\hline Lev & 1 & $0.061 * * *$ & $0.074 * * *$ & $-0.112 * *$ & $0.037 * * *$ & $-0.1 * * *$ & $0.053 * * *$ & $-0.251 * *$ & 0.009 \\
\hline STDebt & $0.046 * * *$ & 1 & $0.143 * * *$ & $-0.202 * *$ & $-0.2 * * *$ & $0.1 * * *$ & $0.22 * * *$ & $-0.233 * *$ & $-0.032 * *$ \\
\hline Size & $0.072 * * *$ & $0.155 * * *$ & 1 & $-0.116 * *$ & $-0.261 * *$ & $0.377 * * *$ & $0.137 * * *$ & $-0.147 * *$ & -0.015 \\
\hline Cash & $-0.135 * *$ & $-0.273 * *$ & $-0.185 * *$ & 1 & $0.047 * * *$ & $-0.032 * *$ & $-0.365 * *$ & $0.094 * * *$ & $0.047 * * *$ \\
\hline MTB & $0.112 * * *$ & $-0.192 * *$ & $-0.266^{* * *}$ & $0.119 * * *$ & 1 & $-0.29 * * *$ & $-0.067^{* * *}$ & $0.563 * * *$ & $0.178 * * *$ \\
\hline LnAge & $-0.097 * *$ & $0.09 * * *$ & $0.304 * * *$ & $-0.116 * *$ & $-0.223 * *$ & 1 & 0.01 & $-0.202 * *$ & $-0.142 * *$ \\
\hline Tang & $0.072 * * *$ & $0.197 * * *$ & $0.139 * * *$ & $-0.358 * *$ & $-0.078 * *$ & -0.012 & 1 & $-0.058 * *$ & $-0.096 * *$ \\
\hline Roa & $-0.224 * *$ & $-0.262 * *$ & $-0.138 * *$ & $0.165 * * *$ & $0.569 * * *$ & $-0.176^{* *}$ & $-0.081 * *$ & 1 & $0.2 * * *$ \\
\hline HP & 0.011 & $-0.032 * *$ & -0.001 & $0.051 * * *$ & 0.136 *** & $-0.145 * *$ & $-0.095 * *$ & $0.191 * * *$ & 1 \\
\hline
\end{tabular}

Table 3. Correlation Matrix

\subsection{Regression Results}

Table 4 reports the results of the regression estimation of models 1 and 2 on analyzing $\mathrm{H} 1$ and $\mathrm{H} 2$. $F$-statistics of the models are significant at $1 \%$. As far as Durbin Watson statistics are in an acceptable range, the outcomes of the table are reliable.

In Eq. 1, the coefficient between financial leverage and investment efficiency is $-0.0259(p<0.01)$, indicating that financial leverage exacerbates investment efficiency. Furthermore, the coefficient of short-term debt with investment efficiency is $-0.0084(p<0.01)$; therefore, it can be concluded that short-term debt decreases investment efficiency, so H1 is supported. In Eq. 2 financial leverage has a coefficient of $-0.0223(p<0.05)$ and in Eq. 3 short-term debt has a coefficient of $-0.0068(p<0.01)$. Therefore, financial leverage and short-term debt in equations where the concern that these two variables may link to each other does not exist, are negatively related to investment efficiency, thus $\mathrm{H} 1$ is reconfirmed.

In Eq. $4, \beta_{1}$ is $-0.0281(p<0.01)$, representing the coefficient between financial leverage and investment efficiency for firms with lower use of short-term debt. $\beta_{1}+\beta_{3}$ is -0.0224 , showing the coefficient between financial leverage and investment efficiency for firms with higher use of short-term debt. Therefore, financial leverage is less negatively related to investment efficiency for firms with higher use of short-term debt than those with lowlevel short-term debt $\left(\beta_{1}<\beta_{1}+\beta_{3}=-0.0281-0.0224\right)$. In short, short-term debt could alleviate the negative association between financial leverage and investment efficiency; as a result, $\mathrm{H} 2$ is supported. 


\begin{tabular}{|c|c|c|c|c|}
\hline Variable & Equation 1 & Equation 2 & Equation 3 & Equation 4 \\
\hline \multirow[t]{2}{*}{ Lev } & $-0.0259 * *$ & $-0.0223 * *$ & & $-0.0281 * * *$ \\
\hline & $(-2.3172)$ & $(-1.9637)$ & & $(-2.6039)$ \\
\hline \multirow[t]{2}{*}{ STDebt } & $-0.0084 * * *$ & & $-0.0068 * * *$ & $-0.0107 * * *$ \\
\hline & $(-5.0376)$ & & $(-3.5853)$ & $(-7.0902)$ \\
\hline \multirow[t]{2}{*}{ Lev $\times$ DumSTDebt } & & & & $0.0057 *$ \\
\hline & & & & $(1.7639)$ \\
\hline \multirow[t]{2}{*}{ Size } & $-0.005 * *$ & 0.0011 & 0.0018 & $-0.005 * *$ \\
\hline & $(-2.3259)$ & $(0.1883)$ & $(0.3021)$ & $(-2.3081)$ \\
\hline \multirow[t]{2}{*}{ Cash } & 0.0124 & 0.0137 & 0.0131 & 0.0122 \\
\hline & $(1.4187)$ & $(1.5046)$ & $(1.407)$ & $(1.38)$ \\
\hline \multirow[t]{2}{*}{ MTB } & -0.0002 & -0.0006 & $-0.0008^{*}$ & -0.0001 \\
\hline & $(-0.9502)$ & $(-1.1225)$ & $(-1.6923)$ & $(-0.9073)$ \\
\hline \multirow[t]{2}{*}{ LnAge } & $0.0066 * * *$ & $0.007 * * *$ & $0.0065 * * *$ & $0.0065 * * *$ \\
\hline & $(2.9961)$ & $(3.5728)$ & $(3.2541)$ & $(2.9625)$ \\
\hline \multirow[t]{2}{*}{ Tang } & -0.0026 & -0.0027 & -0.0038 & -0.0025 \\
\hline & $(-0.2049)$ & $(-0.2116)$ & $(-0.2834)$ & $(-0.1958)$ \\
\hline \multirow[t]{2}{*}{ Roa } & $0.0891 * * *$ & $0.0894 * * *$ & $0.091 * * *$ & $0.0897 * * *$ \\
\hline & $(5.9455)$ & $(6.8947)$ & $(5.9754)$ & $(5.9529)$ \\
\hline \multirow[t]{2}{*}{$\mathrm{HP}$} & -0.0022 & -0.0089 & -0.01 & -0.0022 \\
\hline & $(-1.1796)$ & $(-1.2309)$ & $(-1.4241)$ & $(-1.1709)$ \\
\hline \multirow[t]{2}{*}{ Intercept } & 0.0492 & -0.0679 & -0.0825 & 0.05 \\
\hline & $(1.2221)$ & $(-0.6284)$ & $(-0.779)$ & $(1.2297)$ \\
\hline Cross-section dummies & Yes & Yes & Yes & Yes \\
\hline Year dummies & Yes & Yes & Yes & Yes \\
\hline$R^{2}$ & 0.3496 & 0.3484 & 0.3480 & 0.3497 \\
\hline$F$ & $3.7140 * * *$ & $3.6951 * * *$ & $3.6885 * * *$ & $3.7131 * * *$ \\
\hline$D W$ & 2.19513 & 2.197514 & 2.201084 & 2.19509 \\
\hline Obs. & 8741 & 8741 & 8741 & 8741 \\
\hline
\end{tabular}

*** Significance at $1 \%$ level.

** Significance at $5 \%$ level.

* Significance at $10 \%$ level.

T-statistics in brackets.

See Table 2 for variables definitions.

Table 4. Regression of Investment Efficiency on Financial Leverage, Short-Term Debt and Control Variables

\section{Conclusion}

This study is carried out to analyze the association between financial leverage and investment efficiency as well as the role of short-term debt in this relationship. Previous literature suggested that financial leverage increases firms' risks, cost of financing, and financing constraints and lowers free cash flow; as a result, we predicted that debt volume may be inversely related to investment efficiency. Besides, there are two sub-scenarios in debt financing - short-term and long-term debt. We believed that the main reason for the negative impact of financial leverage on investment efficiency is due to the presence of short-term debt; the reason stems from the default and maturity risk which are imposed upon firms by short-term debt. Thus, the first hypothesis predicted that financial leverage and short-term debt both are inversely related to investment efficiency. This hypothesis was supported.

Agency theory argues that debt volume can mitigate information asymmetry between the two sides by increasing the number of contracts between managers and creditors. Additionally, short-term debt could lessen this conflict more efficiently than long-term debt since short-term debt has shorter maturity and can increase the number of contract renewals more frequently than long-term debt. Therefore, it was predicted in the second hypothesis that the inverse relationship between financial leverage and investment efficiency is more for firms with lower use of short-term debt than for firms with higher use of short-term debt. This hypothesis was confirmed.

These findings recommend corporations domiciled in Asian countries to reduce debt volume due to the inverse relationship between financial leverage and investment efficiency. Furthermore, in case of being unable to minimize debt amounts, they are recommended to replace long-term debt with short-term debt.

\section{References}

- Aggarwal, R. K., \& Samwick, A. A. (2006). Empire-builders and shirkers: Investment, firm performance, and managerial incentives. Journal of Corporate Finance, 12(3), p. 489-515.

https://doi.org/10.1016/j.jcorpfin.2006.01.001 
- $\quad$ Andres, C., Cumming, D., Karabiber, T., \& Schweizer, D. (2014). Do markets anticipate capital structure decisions?-Feedback effects in equity liquidity. Journal of Corporate Finance, 27, p. 133-156. https://doi.org/10.1016/j.jcorpfin.2014.02.006

- Bao, H. (2010). A study on leverage and firm investment: Chinese evidence. Master of Science Thesis, Royal Institute of Technology, (June). Retrieved from https://www.kth.se/polopoly_fs/1.169309!/Menu/general/column-content/attachment/Huijie Bao.pdf

- $\quad$ Barbiero, F., Brutscher, P.-B., Kolev, A., Popov, A., \& Wolski, M. (2018). Misallocation of investment in Europe: The role of debt overhang and credit market distress. In Finance and Investment: The European Case, Oxford University Press, 57-63. https://doi.org/10.1093/oso/9780198815815.003.0003

- Benlemlih, M., \& Bitar, M. (2018). Corporate Social Responsibility and Investment Efficiency. Journal of Business Ethics, 148(3), p. 647-671. https://doi.org/10.1007/s10551-016-3020-2

- Bertrand, M., \& Mullainathan, S. (2003). Enjoying the quiet life? Corporate governance and managerial preferences. Journal of Political Economy, 111(5), p. 1043-1075. https://doi.org/10.1086/376950

- Biddle, G. C., \& Hilary, G. (2006). Accounting quality and firm-level capital investment. Accounting Review, 81, p. 963-982. https://doi.org/10.2308/accr.2006.81.5.963

- $\quad$ Biddle, G. C., Hilary, G., \& Verdi, R. S. (2009). How does financial reporting quality relate to investment efficiency? Journal of Accounting and Economics, 48(2-3), 112-131. https://doi.org/10.1016/j.jacceco.2009.09.001

- Blanchard, O. J., Lopez-de-Silanes, F., \& Shleifer, A. (1994). What do firms do with cash windfalls? Journal of Financial Economics, 36(3), p. 337-360. https://doi.org/10.1016/0304-405X(94)90009-4

- Chen, F., Hope, O. K., Li, Q., \& Wang, X. (2011). Financial reporting quality and investment efficiency of private firms in emerging markets. Accounting Review, 86(4), p. 1255-1288. https://doi.org/10.2308/accr10040

- Childs, P. D., Mauer, D. C., \& Ott, S. H. (2005). Interactions of corporate financing and investment decisions: The effects of agency conflicts. Journal of Financial Economics, 76(3), p. 667-690. https://doi.org/10.1016/j.jfineco.2004.06.012

- Danso, A., Lartey, T., Fosu, S., Owusu-Agyei, S., \& Uddin, M. (2019). Leverage and firm investment: the role of information asymmetry and growth. International Journal of Accounting \& Information Management, 27(1), p. 56-73. https://doi.org/10.1108/IJAIM-10-2017-0127

- Flannery, M. J. (1986). Asymmetric information and risky debt maturity choice. The Journal of Finance, 41(1), p. 19-37. https://doi.org/10.1111/j.1540-6261.1986.tb04489.x

- Flynn, S. (2017). Debt Structure and Future Financing and Investment. Doctoral dissertation, Arizona State University. https://repository.asu.edu/items/44024

- Gomariz, M. F. C., \& Ballesta, J. P. S. (2014). Financial reporting quality, debt maturity and investment efficiency. Journal of Banking \& Finance, 40, p. 494-506. https://doi.org/https://doi.org/10.1016/j.jbankfin.2013.07.013

- González, V. M. (2017). Firm and country determinants of debt maturity: New international evidence. International Finance, 20(3), p. 256-270. https://doi.org/10.1111/infi.12116

- Hadlock, C. J., \& Pierce, J. R. (2010). New evidence on measuring financial constraints: Moving beyond the KZ index. Review of Financial Studies, 23(5), p. 1909-1940. https://doi.org/10.1093/rfs/hhq009

- He, W. P., Lepone, A., \& Leung, H. (2013). Information asymmetry and the cost of equity capital. International Review of Economics \& Finance, 27, p. 611-620. https://doi.org/10.1016/j.iref.2013.03.001

- Heaton, J. B. (2002). Managerial optimism and corporate finance. Financial Management, 31(2), p. $33-45$. https://www.jstor.org/stable/3666221

- Hsu, L.-T., \& Jang, S. (2008). The determinant of the hospitality industry’s unsystematic risk: A comparison between hotel and restaurant firms. International Journal of Hospitality \& Tourism Administration, 9(2), p. 105-127. https://doi.org/10.1080/15256480801907877

- Jensen, M. C. (1986). Agency costs of free cash flow, corporate finance, and takeovers. American Economic Review, 76(2), p. 323-329. https://www.jstor.org/stable/1818789

- Jensen, M., \& Meckling, W. (1976). Theory of the firm: Managerial behaviour, agency costs and ownership. Strategic Management Journal, 3(4), p. 305-360. https://doi.org/10.1016/0304-405X(76)90026-X

- $\quad$ Khan, A., Kaleem, A., Nazir, M. S., \& Khan, K. (2012). Voluntarily contribution and Agency cost of Free Cash Flow: Evidence from Manufacturing sector of Pakistan. J. Basic. Appl. Sci. Res, 2(7), p. 6882-6888. https://lahore.comsats.edu.pk/Papers/Abstracts/146-8588087133582664558.pdf 
- $\quad$ Koh, Y., Lee, S., \& Boo, S. (2009). Does franchising help restaurant firm value? International Journal of Hospitality Management, 28(2), p. 289-296. https://doi.org/10.1016/j.ijhm.2008.10.001

- $\quad$ Lang, L., Ofek, E., \& Stulz, R. M. (1996). Leverage, investment, and firm growth. Journal of Financial Economics, 40(1), p. 3-29. https://doi.org/10.1016/0304-405X(95)00842-3

- $\quad$ Li, Y., He, J., \& Xiao, M. (2019). Risk disclosure in annual reports and corporate investment efficiency. International Review of Economics \& Finance, 63, p. 138-151. https://doi.org/10.1016/j.iref.2018.08.021

- Modigliani, F., \& Miller, M. H. (1958). The cost of capital, corporation finance and the theory of investment. The American Economic Review, 49(4), p. 655-669. https://www.jstor.org/stable/1812919

- Morellec, E., \& Schürhoff, N. (2011). Corporate investment and financing under asymmetric information. Journal of Financial Economics, 99(2), p. 262-288. https://doi.org/10.1016/j.jfineco.2010.09.003

- Myers, S. C. (1977). Determinants of corporate borrowing. Journal of Financial Economics, 5(2), p. 147175. https://doi.org/10.1016/0304-405X(77)90015-0

- $\quad$ Myers, S. C. (1984). Finance theory and financial strategy. Interfaces, 14(1), p. 126-137. https://doi.org/10.1287/inte.14.1.126

- $\quad$ Myers, S. C., \& Majluf, N. S. (1984). Corporate financing and investment decisions when firms have information that investors do not have. Journal of Financial Economics, 13(2), p. 187-221. https://doi.org/10.1016/0304-405X(84)90023-0

- Noravesh, I., \& Yazdani, S. (2010). The Impact of Leverage on Firm Investments in Tehran Stock Exchange (TSE). Journal of Financial Accounting Research, 2(2), p. 35-48. Retrieved from http://far.ui.ac.ir/article_16876.html

- $\quad$ Ortiz-Molina, H., \& Penas, M. F. (2008). Lending to small businesses: The role of loan maturity in addressing information problems. Small Business Economics, 30(4), p. 361-383. https://doi.org/10.1007/s11187-007-9053-2

- Poursoleiman, E., Mansourfar, G., \& Abidin, S. (2020). Financial leverage, debt maturity, future financing constraints, and future investment. International Journal of Islamic and Middle Eastern Finance and Management. https://doi.org/10.1108/IMEFM-10-2019-0430

- Richardson, S. (2006). Over-investment of free cash flow. Review of Accounting Studies, 11(2-3), p. 159189. https://doi.org/10.1007/s11142-006-9012-1

- $\quad$ Ross, S. A. (1977). The determination of financial structure: the incentive-signalling approach. The Bell Journal of Economics, 8(1), p. 23-40. https://www.jstor.org/stable/3003485

- $\quad$ Shleifer, A., \& Vishny, R. W. (1989). Management entrenchment: The case of manager-specific investments. Journal of Financial Economics, 25(1), p. 123-139. https://doi.org/10.1016/0304-405X(89)90099-8

- Tsai, H., \& Gu, Z. (2007). Institutional ownership and firm performance: empirical evidence from US-based publicly traded restaurant firms. Journal of Hospitality \& Tourism Research, 31(1), p. 19-38. https://doi.org/10.1177\%2F1096348006296056

- Verdi, R. S. (2006). Financial reporting quality and investment efficiency. http://dx.doi.org/10.2139/ssrn.930922

- Zeitun, R., \& Haq, M. M. (2015). Debt maturity, financial crisis and corporate performance in GCC countries: a dynamic-GMM approach. Afro-Asian Journal of Finance and Accounting, 5(3), p. 231-247. https://doi.org/10.1504/AAJFA.2015.070291

- Zhai, J., \& Wang, Y. (2016). Accounting information quality, governance efficiency and capital investment choice. China Journal of Accounting Research, 9(4), p. 251-266. https://doi.org/10.1016/j.cjar.2016.08.001

- Zhaoguo, Z., Weifeng, H., \& Jing, C. (2008). Firm leverage and the private benefits of control in Chinese firms. Afro-Asian Journal of Finance and Accounting, 1(1), p. 6-16. https://doi.org/10.1504/AAJFA.2008.016887 